\title{
Determinação do Efeito Antimicrobiano do Óleo Essencial de Capim-Limão Na Sobrevivência de Patógenos em Repolho
}

Terezinha Feitosa Machado (I), Janaína de Oliveira Rebouças (II), Matheus Feitosa de Oliveira (II), Maria Karolina de Araújo Barroso (II), Ana Rafaella Alencar Braz (II)

(I) EMBRAPA - Empresa Brasileira de Pesquisa Agropecuária (R. Dra. sara Mesquita, 2270. Fortaleza-CE), (II) UFC - Universidade Federal do Ceará (Campus do Pici)

\section{Resumo}

O mercado de produtos hortifrutícolas frescos tem crescido de maneira significativa nesta última década. Tradicionalmente, esses produtos não eram alvo de muita preocupação por parte de órgãos regulamentadores, pois eram considerados seguros já que eram lavados e rapidamente consumidos no próprio local de preparo. Com a tendência ao consumo das hortaliças minimamente processadas, a preocupação com riscos de natureza microbiológica torna-se acentuada. Atualmente, o hipoclorito de sódio é o desinfetante mais utilizado na desinfecção de superfície de hortaliças.

Apesar de sua eficiência germicida, o cloro nos alimentos pode induzir à formação de compostos organoclorados, trihalometanos e ácidos haloacéticos que são tóxicos, mutagênicos e carcinogênicos, tornando o seu uso cada vez menos atrativo. Com o objetivo de desenvolver uma estratégia alternativa para sanitização de produtos frescos, neste estudo, o óleo essencial (OE) do capim limão foi utilizado em diferentes tratamentos para a desinfecção de folhas frescas de repolho inoculadas com Escherichia coli, Listeria monocytogenes e Salmonella Typhimurium. Folhas de repolho foram lavadas, individualmente, em água corrente e expostas à luz UV por 20 minutos. Em seguida foram cortadas em pequenos pedaços (20 mm x 20 $\mathrm{mm}$ ) com facas estéreis e inoculadas com culturas puras de cada cepa bacteriana (8 log UFC/g) na superfície adaxial. Após a inoculação, as

\footnotetext{
Referência:

Terezinha Feitosa Machado, Janaína de Oliveira Rebouças, Matheus Feitosa de Oliveira, Maria Karolina de Araújo Barroso, Ana Rafaella Alencar Braz. Determinação do Efeito Antimicrobiano do Óleo Essencial de Capim-Limão Na Sobrevivência de Patógenos em Repolho. In: Anais do 12을 Congresso Latinoamericano de Microbiologia e Higiene de Alimentos - MICROAL 2014 [= Blucher Food Science Proceedings, num.1, vol.1]. São Paulo: Editora Blucher, 2014.

DOI 10.5151/foodsci-microal-268
} 
amostras permaneceram por 45 minutos na cabine de fluxo laminar e em seguida foram armazenadas a $7^{\circ} \mathrm{C} / 24$ horas. Na sequência, as amostras foram transferidas para um Becker contendo solução do OE em diferentes concentrações (500 ppm, 750 ppm e 1000 ppm) e agitadas manualmente por 10 e 15 minutos. Para enumerar os sobreviventes as amostras foram diluídas em série e a população viável foi determinada por plaqueamento em ágar seletivo para cada espécie. O OE de capim-limão mostrou efeito antimicrobiano na sobrevivência dos patógenos avaliados. O tratamento com o óleo na concentração de 1000 ppm, independente do tempo, foi o mais eficaz. Entre as espécies bacterianas Listeria monocytogenes foi a mais sensível, enquanto Escherichia coli foi a mais resistente ao óleo. Este estudo demonstra o potencial das soluções do óleo essencial de capimlimão para inativar L. monocytogenes, S. Typhimurium e E. coli em repolho.

Palavras-Chave: Atividade antimicrobiana, Óleo essencial, Repolho Agência de Fomento: 